\title{
Microbiological quality and presence of extraneous matter in industrialized tomato sauces
}

\section{Qualidade microbiológica e presença de matérias estranhas em molhos de tomate industrializados}

\author{
Laís Anversa ${ }^{1 *}$ (1D), Larissa Fiamengui de Pauli ${ }^{1}$, Eliane da Silva Caria ${ }^{1}$, \\ Thelma Constantino de Assis ${ }^{1}$, Regina Célia Arantes Stancari ${ }^{1}$
}

${ }^{1}$ Instituto Adolfo Lutz (IAL), Centro de Laboratório Regional de Bauru, Núcleo de Ciências Químicas e Bromatológicas, Bauru/SP - Brasil

*Corresponding Author: Laís Anversa, Instituto Adolfo Lutz (IAL), Centro de Laboratório Regional de Bauru, Núcleo de Ciências Químicas e Bromatológicas, Rua Rubens Arruda, Quadra 6, Centro, CEP: 17015-110,

Bauru/SP - Brasil, e-mail: laisanversa@yahoo.com.br

\begin{abstract}
Despite being a staple in the daily diet of the Brazilian population, industrialized tomatoes and their derivatives are often subject to countless contaminants during their production process, which may affect the final quality of these products. This study aimed to investigate the microbiological quality and the presence of extraneous matter in industrialized tomato sauces commercialized in Brazil. To this end, two samples of 21 different "traditional tomato sauce" brands (a total of 42 samples) commercialized in supermarkets in the municipality of Bauru, state of Sao Paulo, Brazil, were analyzed from April to November 2016. Overall, 20 (47.6\%) of the 42 samples analyzed were in disagreement with the current Brazilian legislation. After incubation at 35 to $37^{\circ} \mathrm{C}$ and $55^{\circ} \mathrm{C}$, no changes in the packages and $\mathrm{pH}$ variation $>0.2$ were observed. However, $9.5 \%$ of the samples showed a non-characteristic aspect and $11.9 \%$ presented growth of fungi. Regarding the presence of extraneous matter, $11.9 \%$ of the samples showed rodent hair above the permitted limit (1 in $100 \mathrm{~g}$ ) - indicative of risks to human health, whereas $26.2 \%$ of them contained non-rodent hair - indicative of failure in adopting good manufacturing practices. Mold filament counting was conducted using the Howard method, and $14.3 \%$ of the samples presented values above $40 \%$ (acceptable limit) positive microscopic fields. In addition to subsidizing health surveillance actions, such data highlight the need for quality improvement of the raw material used and greater control during the processing of these products.
\end{abstract}

Keywords: Tomato sauce; Microbiological analysis; Microscopy; Molds; Extraneous matter; Quality.

\section{Resumo}

Apesar de estarem amplamente inseridos na alimentação diária da população, frequentemente, tomates industrializados e seus derivados estão expostos a inúmeras contaminações durante o processo de produção, que podem prejudicar a qualidade dos produtos finais. O objetivo deste estudo foi avaliar a qualidade microbiológica e 
a presença de matérias estranhas em molhos de tomate industrializados, comercializados no Brasil. Para isso, foram colhidas duas amostras, de diferentes lotes, de 21 marcas distintas do produto (totalizando 42 amostras), do tipo "molho de tomate tradicional", comercializadas em supermercados do município de Bauru (SP), no período de abril a novembro de 2016. De forma geral, das 42 amostras analisadas, 20 (47,6\%) estavam em desacordo com as legislações vigentes. Após a incubação dos molhos a $35-37{ }^{\circ} \mathrm{C}$ e $55^{\circ} \mathrm{C}$, não foram observadas alterações das embalagens e variações de $\mathrm{pH}>0,2$. No entanto, 9,5\% das amostras exibiram aspecto não característico do produto e 11,9\% apresentaram crescimento de fungos. Quanto à presença de matérias estranhas, 11,9\% das amostras apresentaram pelos de roedores acima do valor máximo permitido ( $1 \mathrm{em} 100 \mathrm{~g}$ ) - indicativos de riscos à saúde humana -, e $26,2 \%$ exibiram pelos não característicos de roedores - indicativos de falhas na adoção das boas práticas. Na contagem de fungos filamentosos pelo método de Howard, 14,3\% das amostras evidenciaram valores de campos positivos acima de $40 \%$ (limite aceitável). Além de subsidiar as ações de Vigilância Sanitária, tais dados evidenciam a necessidade de melhoria na qualidade da matéria-prima empregada e maior controle durante as etapas de processamento dos produtos.

Palavras-chave: Molho de tomate; Análise microbiológica; Microscopia; Fungos; Matérias estranhas; Qualidade.

\section{Introduction}

The tomato (Lycopersicum sp.) presents wide distribution, and is listed among the produce of greater distribution worldwide. In South America, Brazil leads tomato production for industrial processing, and the largest consumer market for its industrialized derivatives (Instituto Brasileiro de Geografia e Estatística, 2015).

Commonly, industrial tomatoes may present physical, chemical and microbiological contamination, including bacteria, viruses, parasites and fungi, at various stages of the production process: (1) in the field, in contact with soil, water and fertilizers; (2) during harvest, with possible mechanical lesions; (3) in transportation, often associated with excessive stacking (with kneading and breaking) and high temperatures; (4) during processing, through equipment contamination; (5) in storage, due to exposure to inappropriate conditions (Reis \& Lopes, 2012).

The numerous types of physical contamination related to tomato pests, mainly by mites and insects such as whitefly (Bemisia tabaci, biotype B), triplets (Frankliniella schultzei and Thrips palmi), aphids (Myzus persicae and Macrosiphum euphorbiae), tomato pinworm (Tuta absoluta) and tomato fruit borer (Neoleucinodes elegantalis), are capable of causing changes in the vegetative and/or reproductive development of plants and fruits (Moura et al., 2014), and certainly the presence of bacteria (especially of family Enterobacteriaceae) on the tomato surface represents food safety risks, because the fruit may be a source of pathogenic microorganisms (Telias et al., 2011). In fact, in the past decades, tomatoes have been one of the main products responsible for produce-associated salmonellosis in the United States of America (Gravani, 2009).

In Brazil, in order to ensure sanitary control, processed products derived from tomatoes must comply with, among other legislation, Resolution RDC 12 (02/01/2001), which regulates the microbiological standards for food intended to human consumption (Brasil, 2001), and Resolution RDC 14 (03/28/2014), which provides for the presence and tolerance limits of extraneous matter (any macroscopic and/or microscopic material not constituent of the product) in foods and beverages (Brasil, 2014).

Undoubtedly, microbiological analyses and investigations of extraneous matter - such as arthropods and other invertebrates (dead or alive, whole or in parts), parasites, fungi, hard objects, and filth in general - are among the most important parameters to determine the quality of industrial tomatoes, enabling evaluation in terms of processing, storage, distribution for consumption, shelf life, and human health risks (Santos, 2014).

Fungi, especially species of the Fusarium, Alternaria, Stemphylium, Rhizopus, Aspergillus, Penicillium, Geotrichum, Phytophthora and Botrytis genera, are often the main contaminants of tomato fruits, causing 
considerable economic losses to producers and industry (Mailafia et al., 2017), in addition to presenting potential risk to human and animal health, because they may be associated with production of mycotoxins that have hepatotoxic and mutagenic effects (Afsah-Hejri et al., 2013).

Although the fungi can be inactivated in the thermal processing phase during tomato industrialization and, therefore, present negative results in microbiological cultures, their structures (hyphae) remain in the products, indicating that the fruit was contaminated or possible lack of good processing practices. Thus, in practice, mold filament counting by the Howard method is a good quality indicator of the tomatoes used (Association of Official Analytical Chemists, 2005).

Considering that the tomato processing industries require very mature fruits (Centro de Produções Técnicas, 2010), that conventional pasteurization processes do not destroy mycotoxins (Murphy et al., 2006), and the possible occurrence of heat-resistant fungi (Salomão et al., 2008), research addressing the quality of the fruits used and the hygiene conditions involved in production becomes even more relevant.

The general objective of this study was to investigate the microbiological quality and the presence of extraneous matter in industrialized tomato sauces commercialized in Brazil.

\section{Material and methods}

Two samples of 21 different "traditional tomato sauce" industrial brands (a total of 42 samples of different batches), marketed in hermetic packages stable at room temperature, were purchased from supermarkets in the municipality of Bauru, state of Sao Paulo, Brazil, from April to November 2016. It is worth noting that the sample unit consisted of five product packages (from the same batch), which were subjected to different analyses.

After collection, the samples were transported at room temperature to the Instituto Adolfo Lutz, Bauru Regional Laboratory Center (IAL-CLR Bauru), where the analyses were carried out.

Microbiological and physicochemical analyses included the incubation test of the closed packages, followed by analysis of sensorial characteristics and $\mathrm{pH}$ variation. In order to perform the incubation test, three packages were individually wrapped in filter paper; one was incubated at $35-37{ }^{\circ} \mathrm{C}$ for 10 days, one was incubated at $55^{\circ} \mathrm{C}$ for 5 days, and one remained at room temperature (Brasil, 2001). After incubation and evaluation of possible changes in packaging, the other analyses were conducted: sensorial analyses were carried out by comparing the samples, observing their appearance, color, scent and texture (Instituto Adolfo Lutz, 2005) and $\mathrm{pH}$ measurements were performed using a pH-meter (DIGIMED-DM20).

In addition, in the case of samples with sensorial modifications, artificial color analysis was performed according to the techniques 051/IV and 086/IV, which are based on separation and identification of food color by ascending paper chromatography as described in the $4^{\text {th }}$ edition of the Instituto Adolfo Lutz technical manual - Physical-chemical methods for food analysis (Instituto Adolfo Lutz, 2005).

For investigation of the hygiene conditions of the product, counting of mesophilic and thermophilic aerobic bacteria, molds, and yeasts was performed. These analyses were conducted according to the methodologies recommended by the American Public Health Association (APHA) described in the Compendium of Methods for the Microbiological Examination of Foods (American Public Health Association, 2015). Counting of the mesophilic and thermophilic aerobic microorganisms was performed by pour plate method using Plate Count Agar (PCA) at the following incubation conditions: $35 \pm 1{ }^{\circ} \mathrm{C}$ for $48 \mathrm{~h}$ and $55 \pm 1{ }^{\circ} \mathrm{C}$ for $48 \mathrm{~h}$, respectively. Molds and yeasts were investigated by the spread plate technique using Dichloran Rose-Bengal Chloramphenicol (DRBC) agar with incubation at $25^{\circ} \mathrm{C}$ for 5 days.

The methods recommended by the Association of Official Analytical Chemists (AOAC) - Technique 955.46 B (16.13.14) and Technique 965.41 (16.19.02) - were used for the analyses for extraneous matter and mold filament counting by the Howard method, respectively (Association of Official Analytical Chemists, 2005). 
The results were analyzed according to the current legislation - RDC $12(02 / 01 / 2001)(B r a s i l, 2001)$ and RDC 14 (03/28/2014) (Brasil, 2014) - with samples were classified as satisfactory or unsatisfactory. Counting of mesophilic and thermophilic aerobic bacteria, molds, and yeasts was performed only to investigate the hygiene conditions of the product, and the results were not determining for classification of the samples as satisfactory or unsatisfactory.

\section{Results and discussion}

Table 1 shows the results of the microbiological and microscopic analyses of the industrialized tomato sauces marketed in Brazil and evaluated in this study. 
Table 1. Results of the microbiological and microscopic analyses of industrialized tomato sauces commercialized in Brazil.

\begin{tabular}{|c|c|c|c|c|c|c|c|c|c|c|c|c|}
\hline \multirow[b]{2}{*}{ Sample } & \multirow[b]{2}{*}{$\begin{array}{c}\text { Incubation } \\
\text { test }\end{array}$} & \multirow[b]{2}{*}{$\begin{array}{l}\Delta \mathrm{pH} \\
>0.2\end{array}$} & \multirow[b]{2}{*}{ Sensory analysis } & \multirow[b]{2}{*}{$\begin{array}{l}\text { Mesophiles } \\
\text { (CFU/g) }\end{array}$} & \multirow[b]{2}{*}{$\begin{array}{l}\text { Thermophiles } \\
\text { (CFU/g) }\end{array}$} & \multirow{2}{*}{$\begin{array}{c}\text { Yeasts and } \\
\text { Molds (CFU/g) }\end{array}$} & \multicolumn{4}{|c|}{ Extraneous matter (in 100 g) } & \multirow{2}{*}{$\begin{array}{c}\text { Howard } \\
\text { mold count } \\
(\%)\end{array}$} & \multirow{2}{*}{$\begin{array}{c}\text { Overall } \\
\text { evaluation }\end{array}$} \\
\hline & & & & & & & $\begin{array}{c}\text { Insect } \\
\text { fragments }\end{array}$ & $\begin{array}{c}\text { Rodents } \\
\text { hair }\end{array}$ & Mites & $\begin{array}{c}\text { Hair } \\
(*)\end{array}$ & & \\
\hline A1 & $-(* *)$ & - & - & - & - & 10 & 1 & 0.5 & - & 0.5 & 8 & Unsatisfactory \\
\hline B1 & - & - & - & - & - & - & 2 & 1 & - & - & 82 & Unsatisfactory \\
\hline C1 & - & - & - & - & - & - & 1 & - & - & - & 4 & Satisfactory \\
\hline D1 & - & - & - & - & - & - & 1 & 1 & - & - & 10 & Satisfactory \\
\hline E1 & - & - & - & - & - & - & 2 & - & - & 0.5 & 11 & Unsatisfactory \\
\hline F1 & - & - & - & - & - & - & 1 & 0.5 & - & 0.5 & 4 & Unsatisfactory \\
\hline G1 & - & - & - & - & - & - & 1 & - & - & - & 8 & Satisfactory \\
\hline H1 & - & - & - & - & - & - & 1 & 0.5 & - & - & 3 & Satisfactory \\
\hline I1 & - & - & - & - & - & 10 & 2 & 1.5 & - & - & 8 & Unsatisfactory \\
\hline J1 & - & - & - & - & - & - & - & - & - & - & 4 & Satisfactory \\
\hline K1 & - & - & - & - & - & - & 1 & - & - & - & 2 & Satisfactory \\
\hline L1 & - & - & - & - & - & - & - & - & - & - & 55 & Unsatisfactory \\
\hline M1 & - & - & - & - & - & - & 1 & - & - & - & 2 & Satisfactory \\
\hline N1 & - & - & - & - & - & - & 1 & - & - & - & 4 & Satisfactory \\
\hline 01 & - & - & - & - & - & - & 1 & - & - & - & 8 & Satisfactory \\
\hline P1 & - & - & $\begin{array}{l}\text { Non-characteristic } \\
\text { appearance }\end{array}$ & - & - & - & 1 & - & - & - & 98 & Unsatisfactory \\
\hline Q1 & - & - & - & - & - & - & 1 & - & - & - & 8 & Satisfactory \\
\hline R1 & - & - & - & - & - & - & 1 & 1.5 & - & 0.5 & 12 & Unsatisfactory \\
\hline S1 & - & - & - & - & - & - & - & 4.5 & - & 1 & 9 & Unsatisfactory \\
\hline T1 & - & - & $\begin{array}{c}\text { Non-characteristic } \\
\text { appearance }\end{array}$ & - & - & Countless & 3 & - & - & - & 100 & Unsatisfactory \\
\hline U1 & - & - & - & - & - & - & 2 & 2.5 & - & - & 12 & Unsatisfactory \\
\hline A2 & - & - & - & - & - & - & 2 & - & - & 1 & 24 & Unsatisfactory \\
\hline B2 & - & - & - & - & - & - & 4 & - & - & 0.5 & 74 & Unsatisfactory \\
\hline $\mathrm{C2}$ & - & - & - & - & - & - & 1 & - & - & - & 10 & Satisfactory \\
\hline D2 & - & - & - & - & - & - & 4 & - & - & - & 10 & Satisfactory \\
\hline E2 & - & - & - & - & - & - & - & - & - & - & 34 & Satisfactory \\
\hline F2 & - & - & - & - & - & 55 & - & - & - & 0.5 & 10 & Unsatisfactory \\
\hline G2 & - & - & - & - & - & - & - & - & - & - & 10 & Satisfactory \\
\hline $\mathrm{H} 2$ & - & - & - & - & - & - & - & - & - & - & 8 & Satisfactory \\
\hline I2 & - & - & - & - & - & - & - & - & - & 1 & 10 & Unsatisfactory \\
\hline $\mathrm{J} 2$ & - & - & - & - & - & - & 3 & - & - & - & 12 & Satisfactory \\
\hline K2 & - & - & - & - & - & - & 2 & - & - & - & 8 & Satisfactory \\
\hline
\end{tabular}


Microbiological quality and presence of extraneous matter in industrialized tomato sauces

Anversa, L. et al.

Table 1. Contined...

\begin{tabular}{|c|c|c|c|c|c|c|c|c|c|c|c|c|}
\hline \multirow[b]{2}{*}{ Sample } & \multirow{2}{*}{$\begin{array}{c}\text { Incubation } \\
\text { test }\end{array}$} & \multirow{2}{*}{$\begin{array}{c}\Delta \mathrm{pH} \\
>0.2\end{array}$} & \multirow[b]{2}{*}{ Sensory analysis } & \multirow{2}{*}{$\begin{array}{l}\text { Mesophiles } \\
\text { (CFU/g) }\end{array}$} & \multirow{2}{*}{$\begin{array}{l}\text { Thermophiles } \\
\text { (CFU/g) }\end{array}$} & \multirow{2}{*}{$\begin{array}{c}\text { Yeasts and } \\
\text { Molds (CFU/g) }\end{array}$} & \multicolumn{4}{|c|}{ Extraneous matter (in 100 g) } & \multirow{2}{*}{$\begin{array}{c}\text { Howard } \\
\text { mold count } \\
(\%)\end{array}$} & \multirow[b]{2}{*}{$\begin{array}{c}\text { Overall } \\
\text { evaluation }\end{array}$} \\
\hline & & & & & & & $\begin{array}{c}\text { Insect } \\
\text { fragments }\end{array}$ & $\begin{array}{c}\text { Rodents } \\
\text { hair }\end{array}$ & Mites & $\begin{array}{l}\text { Hair } \\
(*)\end{array}$ & & \\
\hline $\mathbf{L 2}$ & - & $\begin{array}{llll}- & \\
\end{array}$ & - & - & $\begin{array}{lll}- & \\
\end{array}$ & $\begin{array}{lll}- & \\
\end{array}$ & 1 & - & $\overline{-}$ & - & 18 & Satisfactory \\
\hline M2 & - & - & - & - & - & - & 2 & 0.5 & - & - & 0 & Satisfactory \\
\hline N2 & - & - & - & - & - & - & 2 & - & - & 0.5 & 6 & Unsatisfactory \\
\hline O2 & - & - & - & - & - & - & 5 & 2 & - & - & 6 & Unsatisfactory \\
\hline $\mathbf{P 2}$ & - & - & $\begin{array}{c}\text { Non-characteristic } \\
\text { appearance }\end{array}$ & - & - & - & 0,5 & - & - & - & 99 & Unsatisfactory \\
\hline Q2 & - & - & - & - & - & - & 1 & - & - & - & 6 & Satisfactory \\
\hline $\mathbf{R 2}$ & - & - & - & - & - & - & 1 & - & - & - & 14 & Satisfactory \\
\hline S2 & - & - & - & - & - & 20 & 1 & - & - & 1 & 8 & Unsatisfactory \\
\hline $\mathbf{T} 2$ & - & - & $\begin{array}{c}\text { Non-characteristic } \\
\text { appearance }\end{array}$ & - & - & - & - & - & - & - & 35 & Unsatisfactory \\
\hline U2 & - & - & - & - & - & - & - & 0.5 & - & - & 4 & Satisfactory \\
\hline
\end{tabular}

*Non-rodent animal hair. **No change or not found. CFU: Colony Forming Unit. $\Delta \mathrm{pH}$ : $\mathrm{pH}$ variation. 
Microbiological analysis (after incubation of the sauces at $35-37^{\circ} \mathrm{C}$ and $55^{\circ} \mathrm{C}$ ) of the 42 samples of different brands of the product showed no changes in the packages and $\mathrm{pH}$ variation $>0.2$. However, four $(9.5 \%)$ samples presented a non-characteristic aspect of the product, and were thus in disagreement with the current legislation.

According to the RDC 276 (22/09/2005), which regards the "Technical Regulation for spices, seasonings and sauces", sauces are products in liquid form, pasty, emulsion or suspension based on seasonings, spices and other ingredients used to prepare or add scent/flavor to food. Product manufacturing must comply with the current legislation of good practices for not adding substances (physical, chemical, or biological) that represent a risk to consumer health (Brasil, 2005).

All the samples with sensory changes (color, odor, texture, and flavor) presented artificial food color (specifically Bordeaux S). These sauces were also in disagreement with the legislation, RDC 04 (01/15/2007), which states that, in cases of products whose name includes the word "tomato", addition of natural and/or artificial food coloring is prohibited (Brasil, 2007). The presence of the artificial food coloring in these samples indicates intentional fraud, because this additive is not allowed for this category of food, and can bring economic loss to the consumer when acquiring the product. In addition, artificial food colorings are not completely innocuous, and can be harmful to human health because they can cause adverse reactions, including allergies, changes in behavior in general, and even carcinogenic effects in cases of prolonged ingestion (Polônio \& Peres, 2009).

None of the samples assessed presented mesophilic and thermophilic aerobic bacteria; however, growth of molds and yeasts was observed in five (11.9\%) samples. As previously reported, fungi occur very often in tomatoes and their derivatives, but considering that these products undergo industrial processing, which includes washing, selection, heat treatment and pasteurization stages, the growth of molds and yeasts detected in microbiological analysis is not expected and may indicate contamination by heat-resistant fungi.

Thermotolerant filamentous fungi are often involved in the deterioration of thermally processed fruit products, because many of them produce ascospores (sexed form of reproduction) that survive thermal treatments and, subsequently, germinate inside the packages, causing great economic losses (Ferreira et al., 2011). In addition, in Brazil, fungicide contamination has been observed in some tomato products since the 1990s, even under aseptic packaging conditions (Kawashima et al., 2002).

Additionally, the occurrence of fungi in tomato sauce samples alert to the possibility of presence of mycotoxins, which may pose serious risks to human health (Pawlowska et al., 2012). Some studies conducted in Germany, Argentina, Switzerland and Brazil have demonstrated presence of mycotoxins in different tomato products, including purée, pulps, juices, ketchups and sauces (Motta \& Soares, 2001; Van de Perre et al., 2013; Santos, 2014).

Analysis for extraneous matter is important both in the selection of raw material for food manufacturing and in monitoring the quality of processed foods. The presence of extraneous material in food products is unpleasant and can pose a serious health hazard to consumers. The main reason for carrying out analyses for extraneous matter in food is to ensure consumers protection from harmful or filthy food products (Tilocca et al., 2015).

Investigation of extraneous matter enables evaluation of the quality of raw material and product processing in order to verify the hygiene conditions employed and protect the health of consumers (Tilocca et al., 2015).

The current Brazilian legislation, more precisely Resolution RDC 14 (03/28/2014), defines two types of extraneous matter: those that indicate health risks and those that do not present risks, but can show that failures in the processes of production, manipulation or storage of the product have occurred. Also in accordance with that legislation, in certain foods, including tomato products, presence of some unavoidable extraneous matter is tolerated (within the limits set), even with the application of good practices. The tolerance limits for this extraneous matter are established according to the following criteria: a) health risk, considering the exposed population, processing, preparation conditions, and how the product is consumed; (b) available national data; c) occurrence of extraneous matter even with adoption of the best available practices; d) existence of international reference (Brasil, 2014).

In the present study, for the presence of extraneous matter indicative of lack of good practices, insect fragments were observed in 32 (76.2\%) of the samples analyzed, but within the tolerance limits established by the Brazilian legislation ( $\leq 10$ fragments in $100 \mathrm{~g}$ ). Mites, whose tolerance limit for food in general is five dead mites per analyzed 
aliquot, were not found in any sample, and fragments of non-rodent hair, which are not tolerated in any type of food, were found in $11(26.2 \%)$ samples, rendering the product unsatisfactory.

Fragments of rodent hair, considered an indicative of health risk, were observed in 12 (28.6\%) samples, of which five (11.9\%) presented values above the maximum tolerance limit (1 fragment in $100 \mathrm{~g}$ ).

Analyzing 130 samples of packaged food products that compose the Brazilian food voucher (sugar, rice, stuffed cookies, crackers, roasted and ground coffee, sweet bars, tomato purée, cassava flour, wheat flour, beans, corn meal, pasta, and salt), Daros et al. (2010) observed extraneous matter of many origins in $71 \%$ of the samples, and found specifically fragments of insects and mites in samples of tomato purée. Similar data were also reported for fruit pulps marketed in the city of São Paulo, Brazil. Insect fragments were detected in pulps of guava (84\%), strawberry (78\%), tomato (61\%) and mango (38\%), whereas rodent hair was observed in pulps of tomato (24\%), guava (3\%), strawberry (1\%) and mango (0.5\%) (Atui et al., 2014).

In this study, neither whole insects nor insect fragments were detected in the analyzed samples. However, it is worth noting that a study conducted by the US Food and Drug Administration (FDA) showed that the presence of whole insects in food is a major cause of consumer complaints (Olsen et al., 2001). Worryingly, insects can carry pathogenic microorganisms that cause foodborne diseases. Many studies have shown several species of flies associated with the transmission of Salmonella spp., Shigella spp., pathogenic Escherichia coli, Vibrio cholerae, Listeria spp., Campylobacter spp., Cryptosporidium parvum, Helicobacter pylori, and diseases caused by rotaviruses (Olsen, 1998).

Rodent hair is often found in tomato processed products. The prevalence of this extraneous matter may be associated with cultivation (open field planting), mechanical harvesting (deep harvesting and with residues), spraying with pesticides that hinders the removal of hair attached to the epidermis of the fruit, among other factors (Moretti, 2008; Atui et al., 2014).

Despite the difficulty in eliminating rodents in the field, their identification at any stage of the production chain represents a serious problem to consumer health, because rodents can transmit several diseases, such as leptospirosis, bubonic plague, salmonellosis, as well as different viruses (Meerburg et al., 2009).

Mold filament counting by the Howard method showed that 41 (97.6\%) samples had mycelial filaments and six (14.3\%) samples presented values above the maximum permitted ( $40 \%$ positive microscopic fields).

Corroborating the findings of this study, Correia \& Roncada (2002) also observed high mold filament counting in fruit paste in sweets marketed in São Paulo, Brazil.

The presence of thermotolerant filamentous fungi in tomato sauces does not necessarily pose a risk to human health, but indicates the use of deteriorated raw material (Association of Official Analytical Chemists, 2005). According to the Instituto Brasileiro de Frutas (2014), the tomato processing industry fails to comply with requirements by the Howard method because of average air humidity $>50 \%$, lack of effective detergent grid and chemical control, intercellular infection between tomato cultures, and lack of the technological solutions for separation of fruits with lesions (Instituto Brasileiro de Frutas, 2014). In California (USA), 25\% of tomatoes without visible changes were colonized by molds (Doan et al., 2016).

However, in the scope of the production systems, a series of factors limiting to the optimization of industrial tomato production is still observed. The occurrence of fungi in products derived from this fruit could be avoided through culture management, greater efficiency of irrigation techniques, levels of fertilization, crop rotation, soil preparation, beds suitable for mechanized harvesting, weed control, and ecological management of pests and diseases (Melo \& Vilela, 2005).

Certainly, insect fragments, rodent and non-rodent hair, filamentous fungi, and other filth found in tomato sauces originate not only from the raw material (due to ecological, environmental and crop management factors), but also from lack of good manufacturing practices and inadequate practices in the production, storage and distribution chain (Moretti, 2008). Regardless, producers and manufacturers should always seek to ensure the integrity and quality of food products. 


\section{Conclusion}

In general, of the 42 samples of tomato sauce analyzed, $20(47.6 \%)$ samples were unsatisfactory and in disagreement with the Brazilian legislation, because they presented sensory changes, rodent and non-rodent hair, and/or mold filament counting above the maximum permitted values.

Therefore, the present study presents an overview of the quality of the industrialized tomato sauces marketed in the Brazil, pointing mainly to the presence of extraneous matter, whether they indicate a risk to human health or lack of good manufacturing practices.

There are still major technical, economic and social challenges regarding the food safety of tomato products. It is essential that the agricultural productive and industrial sectors act in an increasingly integrated way, seeking to add technologies in order to improve the quality of the raw material used and increase the control during the stages of product processing.

Finally, the findings of this study can subsidize health surveillance actions, contribute to the improvement of products and, consequently, protect the health and rights of consumers.

\section{References}

Afsah-Hejri, L., Jinap, S., Hajeb, P., Radu, S., \& Shakibazadeh, S. (2013). A review on mycotoxins in food and feed: Malaysia case study. Comprehensive Reviews in Food Science and Food Safety, 12(6), 629-651. http://dx.doi.org/10.1111/1541-4337.12029

American Public Health Association - APHA. (2015). Compendium of methods for the microbiological examination of foods. Washington: APHA.

Association of Official Analytical Chemists - AOAC. (2005). Official methods of analysis of AOAC International. Gaithersburg: APHA.

Atui, M. B., Silva, A. M., Marciano, M. A. M., Franco, V. A., Chasin, L. B., Ferreira, A. R., Fioravanti, M. I. A., Mattos, E. C., \& Nogueira, M. D. (2014). Monitoring the extraneous matters in pulps of tomato, guava, mango and strawberry marketed during the seasons of the year. Revista do Instituto Adolfo Lutz, 73(4), 325-330.

Brasil. Agência Nacional de Vigilância Sanitária - ANVISA. (2001, janeiro 10). Aprova o regulamento técnico sobre padrões microbiológicos para alimentos (Resolução RDC n 12, de 2 de janeiro de 2001). Diário Oficial [da] República Federativa do Brasil, Brasília.

Brasil. Agência Nacional de Vigilância Sanitária - ANVISA. (2005, setembro 23). Aprova o Regulamento técnico para especiarias, temperos e molhos (Resolução RDC n 276, de 22 de setembro de 2005). Diário Oficial [da] República Federativa do Brasil, Brasília.

Brasil. Agência Nacional de Vigilância Sanitária - ANVISA. (2007, janeiro 17). Atribuição de aditivos e seus limites máximos para a categoria de alimentos 13: Molhos e condimentos (Resolução RDC n 4, de 15 de janeiro de 2007). Diário Oficial [da] República Federativa do Brasil, Brasília.

Brasil. Agência Nacional de Vigilância Sanitária - ANVISA. (2014, janeiro 31). Dispõe sobre matérias estranhas macroscópicas e microscópicas em alimentos e bebidas, seus limites de tolerância e dá outras providências (Resolução RDC $\mathrm{n}^{\circ} 14$, de 28 de março de 2014). Diário Oficial [da] República Federativa do Brasil, Brasília.

Centro de Produções Técnicas - CPT. (2010). Tomate industrial: O Brasil está entre os dez maiores produtores da hortaliça no mundo. Retrieved in 2011, January 20, from http://www.cpt.com.br/artigos/tomate-industrial-o-brasil-esta-entre-os-dez-maioresprodutores-dahortalica-no-mundo

Correia, M., \& Roncada, M. J. (2002). Padronização de método e quantificação de matérias estranhas e filamentos micelianos. Revista do Instituto Adolfo Lutz, 61(2), 85-90.

Daros, V. S. M. G., Prado, S. P. T., Martini, M. H., Graciano, R. A. S., Stancari, R. C. A., Gonzaga, Z. M., Chiarini, P. F. T., Yamamoto, I. T., Silva, M. L. P., Silva, A. M., Marciano, M. A. M., Nogueira, M. D., \& Atui, M. B. (2010). Alimentos embalados que compõem as cestas básicas: Avaliação microscópica e da rotulagem. Revista do Instituto Adolfo Lutz, 69(4), 525-530.

Doan, H. K., Perez, K., Davis, R. M., \& Slaughter, D. C. (2016). Survey of molds in california processing tomatoes. Journal of Food Science, 81(11), M2785-M2792. PMid:27711969. http://dx.doi.org/10.1111/1750-3841.13525

Ferreira, E. H. R., Masson, L. M. P., Rosenthal, A., Souza, M. L., Tashima, L., \& Massaguer, P. R. (2011). Termorresistência de fungos filamentosos isolados de néctares de frutas envasados assepticamente. Brazilian Journal of Food Technology, 14(3), 164-171. http://dx.doi.org/10.4260/BJFT2011140300021

Gravani, R. B. (2009). The role of Good Agricultural Practices in produce safety. In X. Fan, B. A. Niemira, C. J. Doona, F. E. Feeherry \& R. B. Gravani (Eds.), Microbial safety of fresh produce (pp. 101-117). Singapore: IFT Press Series. http://dx.doi.org/10.1002/9781444319347.ch5.

Instituto Adolfo Lutz - IAL. (2005). Métodos físico-químicos para análise de alimentos. São Paulo: IAL.

Instituto Brasileiro de Frutas - IBRAF. (2014). Alerta técnico legal 01/2014. Retrieved in 2017, October 31, from www.ibraf.org.br/vst/arquivos/153115.pdf

Instituto Brasileiro de Geografia e Estatística - IBGE. (2015). Levantamento sistemático da produção agrícola. Retrieved in 2015 February 13, from http://www.ibge.gov.br/home/estatistica/indicadores/agropecuaria/lspa 
Kawashima, L. M., Soares, L. M. V., \& Massaguer, P. R. (2002). The development of an analytical method for two mycotoxins, patulin and verruculogen, and survey of their presence in commercial tomato pulp. Brazilian Journal of Microbiology, 33(3), 269-273. http://dx.doi.org/10.1590/S1517-83822002000300017

Mailafia, S., Okoh, G. R., Olabode, H. O. K., \& Osanupin, R. (2017). Isolation and identification of fungi associated with spoilt fruits vended in Gwagwalada market, Abuja, Nigeria. Veterinary World, 10(4), 393-397. PMid:28507410. http://dx.doi.org/10.14202/vetworld.2017.393-397

Meerburg, B. G., Singleton, G. R., \& Kijlstra, A. (2009). Rodent-borne diseases and their risks for public health. Critical Reviews in Microbiology, 35(3), 221-270. PMid:19548807. http://dx.doi.org/10.1080/10408410902989837

Melo, P. C. T., \& Vilela, N. J. (2005). Desafios e perspectivas para a cadeia brasileira do tomate para processamento industrial. Horticultura Brasileira, 23(1), 154-157. http://dx.doi.org/10.1590/S0102-05362005000100032

Moretti, C. L. (2008). Proposição de revisão da RDC no 175 de 8 de julho de 2003 à luz da realidade da cadeia produtiva de tomates para processamento industrial. Brasília: Embrapa.

Motta, S., \& Soares, L. M. V. (2001). Survey of Brazilian tomato products for alternariol, alternariol monomethyl ether, tenuazonic acid and cyclopiazonic acid. Food Additives and Contaminants, 18(7), 630-634. PMid:11469319. http://dx.doi.org/10.1080/02652030117707

Moura, A. P., Michereff Filho, M., Guimarães, J. A., \& Liz, R. S. (2014). Manejo integrado de pragas do tomateiro para processamento industrial. Embrapa Hortaliças, 129, 2-6.

Murphy, P. A., Hendrich, S., Landgren, C., \& Bryant, C. M. (2006). Food mycotoxins: An update. Journal of Food Science, 71(5), R51R65. http://dx.doi.org/10.1111/j.1750-3841.2006.00052.x

Olsen, A. R. (1998). Regulatory action criteria for filth and other extraneous materials. III. Review of flies and foodborne enteric disease. Regulatory Toxicology and Pharmacology, 28(3), 199-211. PMid:10049791. http://dx.doi.org/10.1006/rtph.1998.1271

Olsen, A. R., Gecan, J. S., Ziobro, G. C., \& Bryce, J. R. (2001). Regulatory action criteria for filth and other extraneous materials. V. strategy for evaluating hazardous and nonhazardous filth. Regulatory Toxicology and Pharmacology, 33(3), 363-392. PMid:11407939. http://dx.doi.org/10.1006/rtph.2001.1472

Pawlowska, A. M., Zannini, E., Coffey, A., \& Arendt, E. K. (2012). Green preservatives: Combating fungi in the food and feed industry by applying antifungal lactic acid bacteria. Advances in Food and Nutrition Research, 66, 217-238. PMid:22909981.

http://dx.doi.org/10.1016/B978-0-12-394597-6.00005-7

Polônio, M. L. T., \& Peres, F. (2009). Consumo de aditivos alimentares e efeitos à saúde: Desafios para a saúde pública brasileira. Cadernos de Saúde Pública, 25(8), 1653-1666. PMid:19649407. http://dx.doi.org/10.1590/S0102-311X2009000800002

Reis, A., \& Lopes, C. A. (2012). Doenças caudadas por fungos e distúrbios fisiológicos. In F. M. V. T. Clemente \& L. S. Boiteux (Eds.), Produção de tomate para processamento industrial (pp. 179-202). Brasília: Embrapa.

Salomão, B. C. M., Massaguer, P. R., \& Aragão, G. M. F. (2008). Isolamento e seleção de fungos filamentosos termorresistentes em etapas do processo produtivo de néctar de maçã. Food Science and Technology, 28(1), 116-121. http://dx.doi.org/10.1590/S010120612008000100017

Santos, G. G. (2014). Qualidade físico-química, microbiológica e ocorrência de micotoxinas de Alternaria alternata em derivados de tomate (Tese de doutorado). Programa de Pós-graduação em Nutrição Humana, Departamento de Nutrição, Faculdade de Ciências da Saúde, Universidade de Brasília, Brasília.

Telias, A., White, J. R., Pahl, D. M., Ottesen, A. R., \& Walsh, C. S. (2011). Bacterial community diversity and variation in spray water sources and the tomato fruit surface. BMC Microbiology, 11(1), 81. PMid:21510867. http://dx.doi.org/10.1186/1471-2180-11-81

Tilocca, M. G., Caneglias, E., Vodret, B., Mancuso, M. R., Zimmardi, A., Manno, C., \& Schiavo, M. R. (2015). Analysis of foreign matter in foodstuffs using the light filth test: Report 2012-2013. Italian Journal of Food Safety, 4(3), 4504. PMid:27800401. http://dx.doi.org/10.4081/ijfs.2015.4504

Van de Perre, E., Deschuyffeleer, N., Jacxsens, L., Vekeman, F., Van Der Hauwaert, W., Asam, S., Rychlik, M., Devlieghere, F., \& De Meulenaer, B. (2013). Screening of moulds and mycotoxins in tomatoes, bell peppers, onions, soft red fruits and derived tomato products. Food Control, 37, 165-170. http://dx.doi.org/10.1016/j.foodcont.2013.09.034

Funding: None. 